\title{
Tonga Language (Tonga Islands)
}

National Cancer Institute

\section{Source}

National Cancer Institute. Tonga Language (Tonga Islands). NCI Thesaurus. Code C154173.

An Austronesian language of the Polynesian branch spoken as a national language in Tonga. 